\title{
The Impact of Behavioral Aspects on Investment Decision Making
}

\author{
Ninditya Nareswari ${ }^{\left.1^{*}\right)}$, Alifia Salsabila Balqista ${ }^{2)}$, Nugroho Priyo Negoro ${ }^{3)}$ \\ $\left.{ }^{*}, 2,3\right)$ Jurusan Manajemen Bisnis, Fakultas Desain Kreatif dan Bisnis Digital, \\ Institut Teknologi Sepuluh Nopember
}

Kampus ITS Sukolilo, Surabaya, Jawa Timur, Indonesia, 60111

E-mail: ninditya@its.ac.id ${ }^{\left.1^{*}\right)}$

\begin{abstract}
This study aims to investigate the impact of behavioral aspects (sentiment investor, overconfidence, salience, overreaction, and herd behavior) on investment decision making. The sample contained 413 individual investors-used partial least square structural equation modeling (PLS-SEM) as a data analysis technique. The results showed that sentiment investors, overconfidence, salience, overreaction, and herd behavior positively affect investment decision making. The finding of this study has important implications for the investor to understand themselves to anticipate bias in investment decision making.
\end{abstract}

Keyword: Behavioral Finance; Capital Market; Investment Decision

\section{INTRODUCTION}

The development of investment activity in the Indonesian capital market has grown rapidly in the last 10 years $(2008-2018)$. This can be seen from the increased performance of the Composite Stock Price Index (IHSG). At the end of 2008, the IHSG was at the level of 1,355, while at the end of 2018 the JCI reached 6,194. The IHSG's performance continues to increase, in line with the larger market capitalization. Based on the Indonesia Stock Exchange's Annual Statistics Report, the market capitalization in 2008 was IDR 1,076 trillion. Meanwhile, at the end of 2018 the IHS market capitalization value reached IDR 7,023 trillion. In addition, the number of investors in the Indonesian capital market is also increasing. From the end of December 2017 to 26 December 2018, the number of Single Investor Identification (SID) grew 44\% to $1,613,165$ SID (KSEI, 2018). This amount is a consolidated single investor identification (SID) number with a specific number of share investors being 851,662 SID. Based on the type of investor in the Indonesian Capital Market, it is known that individual investors dominate at $99.17 \%$ (KSEI, 2019). The results of these facts indicate that the increasing activity of investing in stocks in Indonesia cannot be separated from the investment decisions made by investors.

As knowledge develops, a new paradigm called behavioral finance emerges. Investment decision making is also closely related to financial behavior. Financial behavior is a study that studies how psychological phenomena affect the financial aspect (Shefrin, 2000). 
Financial behavior scope aims to understand the implications of investor behavior in the market concerning making decisions based on psychological factors. Krishnamurti (2009) reveals that there are limitations in investors' ability in fundamental analysis and technical analysis to determine stock value. Investors tend to be irrational when conducting stock transactions in the capital market because investors' decisions are unconsciously influenced by psychological behavior. Puspitaningtyas (2013) proves that investors in Indonesia in the investment decision-making process consider accounting factors. However, investor psychology, which is reflected as a personal signal, is more dominant in consideration of decisions. Luong and Ha (2011) show that behavioral factors influence investment decision making, namely herding, prospect theory, and market reactions. Based on the previous literature, the behavioral factors examined are investor sentiment, overconfidence, salience, overreaction, and herding behavior.

The Indonesian capital market is least efficient In a least efficient market, such investor sentiment also reflected in stock prices. Investor sentiment is investors' confidence in the company's future cash flows that are not supported by (fundamental) accounting information (Lestari and Yulianto, 2018). Changseng and Yongfeng (2012) prove that the role of investor sentiment in forming yields and changes in investor sentiment must be considered as an important systemic risk in stock price determination and portfolio management.

The second variable tested in this study is overconfidence. Kufepaksi (2007) shows that some market behavior has overconfidence where they tend to predict stock market prices inaccurately, resulting in biased market prices. Biais et al. (2002) found that overconfidence behavior causes the tendency of investors to invest in stocks that do not provide profits. Investors who show overconfidence behavior generally have an impact on low investment returns because they fail to diversify their portfolios appropriately.

The third behavioral factor that is tested for its influence in this study is salience. Chaudary (2018) shows that salience has a positive effect on short-term and long-term investment decisions. Salience itself is a tendency to feel more comfortable choosing the familiar (salient) when faced with various risk options, especially in terms of making quick decisions. Yalcin et al. (2016) revealed that investors with a lower level of investment experience are relatively more receptive to signals such as shares of companies with good media attention.

The fourth behavioral factor tested for its effect in this study is overreaction. Excessive reactions occur because investors give too high a price weight to good news (good news) and instead set prices too low on bad news is referred to overreaction (Prastiyo, 2012). Ottemoesoe 
and Malelak (2014) found that overreaction occurred in Southeast Asia which includes Indonesia, Malaysia, Thailand and the Philippines. In addition, they revealed that investors who make transactions on the Indonesian stock exchange tend to be more reactive or overreacted to negative information than positive information. This indicates that an excessive investor reaction is driving significant price movements down or up.

The last behavioral factor that was tested in this study was herding behavior. This behavior can cause a stock market bubble (when the stock price soars above its fair value) and market crashes (Baker et al., 2017). Herding is more likely to occur in developing markets (Chang et al., 2000). Thus, the Indonesian capital market, which is included in the developing market category, can also predict the herding behavior. Researchers focus on herding behavior because its impact on changes in stock prices can affect the attributes of risk and return models.

In line with previous study, this study examines the role of behavioral aspect on investment decision making. For investor, The phenomenon of a market crash in the Indonesian Capital Market that are still less attractive. Investor still focus on buy-sell action without considering the factors that influence investment decision making. Empirical studies prove that investors are not fully rational, but investment decisions are also driven by behavior. This study offer another perspective related to the investor behavior in investment decision making.

\section{Investor Sentiment}

There are two crucial things in investment, returns, and risks. Investors want maximum returns with minimal risk. Another equally important component is the volatility of the stock returns. Brown (1999) states that if noise traders influence prices and the signal from the noise is sentiment. Brown and Cliff (2004) investigate investor sentiment and short-term returns on market aggregates. Using two surveys of investor sentiment, namely a daily survey by the American Association of Individual Investors and a weekly survey by Investor Intelligence, they found that the level of sentiment was highly correlated with the volatility of market returns.

$\mathrm{H}_{1}$ : Investor sentiment has a positive impact on investment decision making

\section{Overconfidence}

The more an investor feels that he has high competence in the capital market, the more often the investor will trade. Investors who are of mature age do not consider another investment factor in their investment activities because they are sure and confident with their ability. (Christanti and Mahastanti, 2011). Glaser and Weber (2007) found that investors who 
have above average perceptions regarding investment competence and past performance will be more active in trading on financial markets. Ivada (2010) proves that in Indonesia, demographic characteristics, namely male gender, age, and high education level, will cause investors to feel that they have a high perception of competence. Investors who have this perception will more often make investment decisions.

$\mathrm{H}_{2}$ : Overconfidence has a positive impact on investment decision making

\section{Salience}

Salience influences investors' investment decisions. This biased behavior is unavoidable because investment decisions involve choosing one right option from several options that require judgment. The process of selecting alternatives requires effort and time. Therefore, investors use salience to overcome difficulties in the decision-making process (Yalcin et al., 2016). Several studies reveal that investors choose to invest in companies they are more familiar with because doing so tends to increase their level of confidence and optimism (Huberman, 2001; Barber et al., 2005).

$\mathrm{H}_{3}$ : Salience has a positive impact on investment decision making

\section{Overreaction}

Investment decisions generally involve a variety of information, both public and private information. Information is a critical component that triggers investors to adopt investment strategies that are considered feasible and profitable. Daniel et al. (1998) stated that overreaction occurs because of investors' confident behavior who obtain private information. Del Giudice and Paltrinieri (2017) proved an overreaction by retail investors in two events, namely the Arab Spring and Ebola, because these two events received a higher media attention level. Ottemosoe and Malelak (2014) have proven that investors who make transactions on the Indonesian stock exchange tend to be more reactive or overreacted to negative information than positive information. This overreaction is influenced by news or certain investment information, but investors' behavior has a significant influence.

$\mathrm{H}_{4}$ : Overreaction has a positive impact on investment decision making

\section{Herding}

Older people have more investment experience from the age prospect, so they have different thoughts from young people in investing. Also, Eagly and Carli (1981) showed that women tend to have more herding behavior than men. Waweru et al. (2008) found that herding can drive stock investment decision making and create momentum. Waweru et al. (2008) also concluded that others' decisions significantly influence an investor's buying and selling decisions. Agarwal et al. (2011) provide empirical evidence of herding behavior by 
brokerage firms in the Indonesian market. Herding behavior is not only limited to individual investors but also affects institutional investors.

$\mathrm{H}_{5}$ : Herding has a positive impact on investment decision making

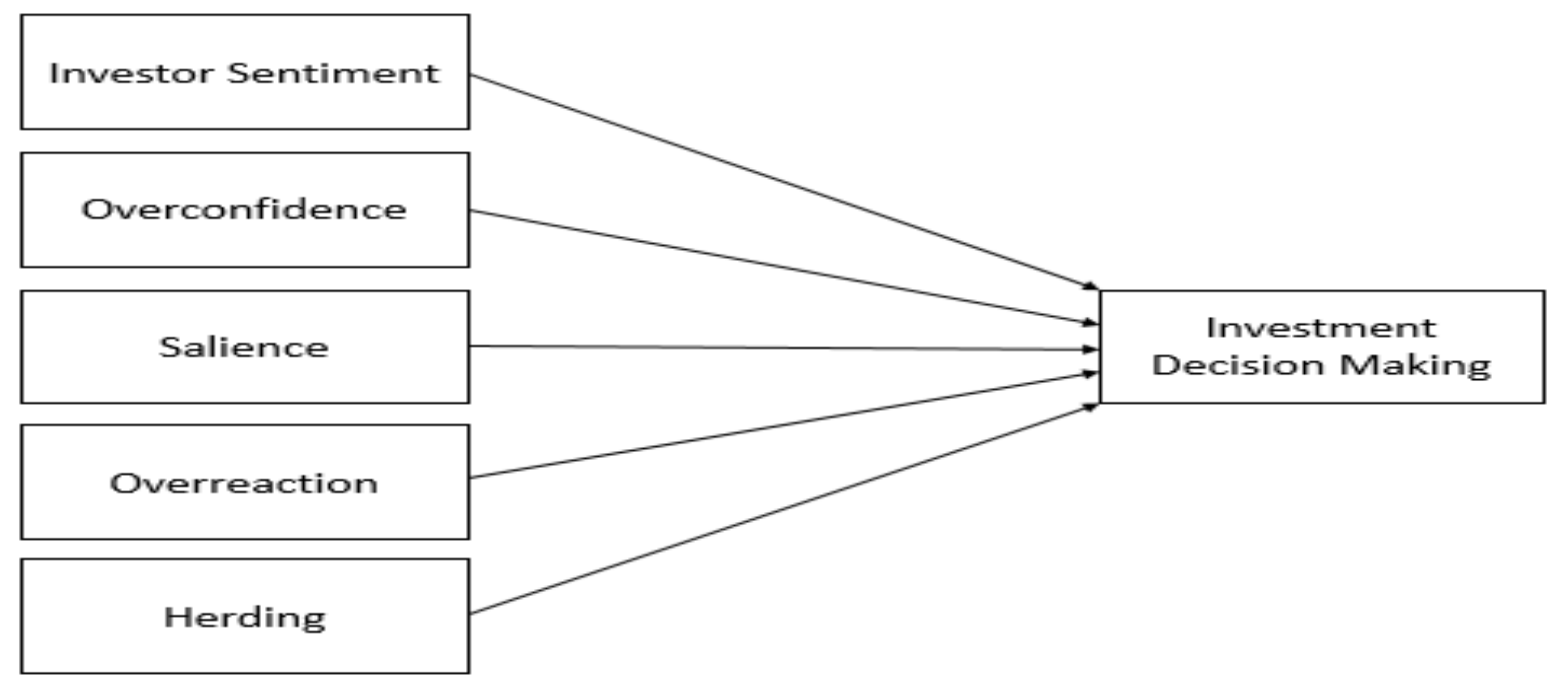

Figure 1. Research Framework

\section{RESEARCH METHODS}

In this study, the questionnaire was distributed online and offline. The questionnaire is distributed online by filling out a self-administered questionnaire where respondents fill out the questionnaire independently. In distributing the questionnaire online, researchers will distribute the online form in the chat room of the investor community at Telegram and the Capital Market Study Group/ Kelompok Studi Pasar Modal (KSPM) in various universities in Indonesia. The questionnaire will also be distributed via personal chat to relations and uploads on the researchers' social media. The Telegram and KSPM share communities of various universities in Indonesia were chosen because of many discussions about the capital market and the prospects for issuers and the market going forward. In addition, offline questionnaires will be distributed to several universities in Surabaya, especially those with the Investment Gallery.

Table 1. The Operational Definition of Variables

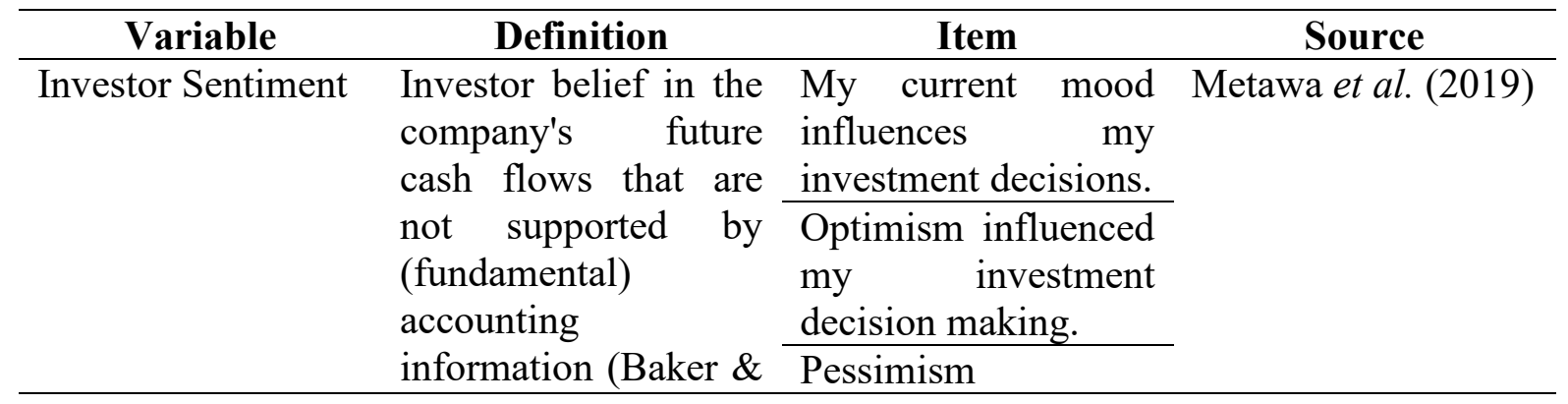




\begin{tabular}{|c|c|c|c|}
\hline & Wurgler, 2006). & $\begin{array}{lr}\text { influenced } & \text { my } \\
\text { investment } & \text { decision } \\
\text { making. } & \\
\end{array}$ & \\
\hline \multirow[t]{5}{*}{ Overconfidence } & \multirow{5}{*}{$\begin{array}{l}\text { Excessive belief in } \\
\text { the abilities, skills } \\
\text { and knowledge of } \\
\text { individuals (Hvide, } \\
\text { 2002) }\end{array}$} & $\begin{array}{l}\text { I have the skills and } \\
\text { expertise needed to } \\
\text { invest in the Capital } \\
\text { Market. }\end{array}$ & \multirow[t]{5}{*}{$\begin{array}{l}\text { Metawa et al. } \\
(2019), \text { Abdin et al. } \\
(2017)\end{array}$} \\
\hline & & $\begin{array}{l}\text { I trust my data } \\
\text { source. }\end{array}$ & \\
\hline & & $\begin{array}{l}\text { I have the ability to } \\
\text { analyze new } \\
\text { information on the } \\
\text { Capital Market. }\end{array}$ & \\
\hline & & $\begin{array}{l}\text { I do trade } \\
\text { transactions myself. }\end{array}$ & \\
\hline & & $\begin{array}{l}\text { I am quite aware of } \\
\text { electronic trading } \\
\text { transactions. }\end{array}$ & \\
\hline \multirow[t]{6}{*}{ Salience } & \multirow{6}{*}{$\begin{array}{l}\text { Tendency to feel } \\
\text { more comfortable } \\
\text { choosing the familiar } \\
\text { stock (Fox \& } \\
\text { Tversky, 1995). }\end{array}$} & Investing in & \multirow{6}{*}{$\begin{array}{l}\text { Yalcin et al. (2016), } \\
\text { Chaundary (2018) }\end{array}$} \\
\hline & & companies that have & \\
\hline & & $\begin{array}{l}\text { good branding is } \\
\text { important. }\end{array}$ & \\
\hline & & $\begin{array}{l}\text { I prefer to invest in } \\
\text { companies whose } \\
\text { products I like. }\end{array}$ & \\
\hline & & $\begin{array}{l}\text { I believe in buying } \\
\text { company stock in my } \\
\text { own country. }\end{array}$ & \\
\hline & & $\begin{array}{l}\text { I prefer investing in } \\
\text { domestic stocks } \\
\text { because they give a } \\
\text { benefit to the } \\
\text { domestic economy. }\end{array}$ & \\
\hline \multirow[t]{5}{*}{ Overreaction } & \multirow{5}{*}{$\begin{array}{l}\text { Investors overreact to } \\
\text { unexpected news (De } \\
\text { Bondt \& Thaler, } \\
\text { 1985) }\end{array}$} & $\begin{array}{l}\text { I respond quickly to } \\
\text { new information on }\end{array}$ & \multirow[t]{5}{*}{ Metawa et al. (2019) } \\
\hline & & the Capital Market. & \\
\hline & & $\begin{array}{l}\text { I think twice before } \\
\text { making investment } \\
\text { decisions when there } \\
\text { is random } \\
\text { information. }\end{array}$ & \\
\hline & & $\begin{array}{l}\text { I think again before } \\
\text { making investment } \\
\text { decisions when there } \\
\text { is unreliable } \\
\text { information. }\end{array}$ & \\
\hline & & $\begin{array}{l}\text { My response } \\
\text { depends on the } \\
\text { information } \\
\text { obtained. }\end{array}$ & \\
\hline
\end{tabular}




\begin{tabular}{|c|c|c|c|}
\hline Herding Behavior & $\begin{array}{l}\text { The tendency of } \\
\text { investor behavior to } \\
\text { follow the actions of } \\
\text { other investors } \\
\text { (Luong \& Ha, 2011) }\end{array}$ & $\begin{array}{l}\text { I make decisions } \\
\text { based on the majority } \\
\text { of other investors' } \\
\text { decisions. } \\
\text { I make decisions } \\
\text { based on stock } \\
\text { movements. } \\
\text { I am not confident in } \\
\text { making different } \\
\text { decisions than the } \\
\text { majority of investors } \\
\text { in the Capital } \\
\text { Market. } \\
\text { Fast movements in } \\
\text { the market influence } \\
\text { my decision. }\end{array}$ & Metawa et al. (2019) \\
\hline $\begin{array}{l}\text { Investment } \\
\text { Decision Making }\end{array}$ & $\begin{array}{l}\text { Purchasing and } \\
\text { selling decisions } \\
\text { made by investors } \\
\text { based on fundamental } \\
\text { / technical analysis / } \\
\text { other sources of } \\
\text { information (Metawa } \\
\text { et al., 2019). }\end{array}$ & $\begin{array}{l}\text { I consider the stock } \\
\text { index when I make } \\
\text { investment decisions. } \\
\text { I consider sectoral } \\
\text { indices when I make } \\
\text { investment decisions. } \\
\text { Trading volume } \\
\text { affects my } \\
\text { investment decisions. } \\
\text { I consider the } \\
\text { opinions of brokers } \\
\text { when making } \\
\text { investment decisions. }\end{array}$ & $\begin{array}{l}\text { Yalcin et al. (2016), } \\
\text { Chaundary (2018) }\end{array}$ \\
\hline
\end{tabular}

All questionnaires were assessed on a five-point likert scale of strongly disagree (1) to strongly agree (5). The criteria for respondents in this study are individual stock investors with at least one year of active investment experience. Used slovin' formula with a $5 \%$ error rate, 413 samples was collected. This study used the Partial Least Square- Structural Equation Model (PLS-SEM) as a method. PLS-SEM is a suitable method when the main objective is to examine a relationship, direction, and strength of variables. Validity and reliability assessments are obtained through measurement of the outer model. The validity test is conducted to test whether the items or scales in the questionnaire can measure what should be measured. Meanwhile, the reliability test is to test whether the measuring instrument used in the study can reveal what is to be measured is appropriate and accurate. Inner model measurements are conducted to evaluate the suitability of research hypotheses and help distinguish between relevant causal hypotheses and those that do not support empirical evidence (Hair et al., 2017). Table 1 showed the operational definition used in this study. 


\section{RESULT AND DISCUSSION}

Table 2 shows the demographic characteristics of the respondents. As shown in table 2, most of respondents were male $(65,6 \%),<25$ years old $(74,6 \%)$, have portfolio less than 5.000 .000 rupiah $(57,1 \%)$, and $1-5$ years of experience in investment $(93 \%)$. The validity and reliability test were used to evaluate the model. As shown in Table 3, all AVEs were above 0,5 indicates an acceptable model. All alphas values and composite reliability values exceed 0,6 , which indicated that each construct's reliability was reasonably satisfied (Table 3 ).

Table 2. Demographic Characteristic

\begin{tabular}{|c|c|c|}
\hline Characteristic & Frequency & Percentage (\%) \\
\hline \multicolumn{3}{|l|}{ Age } \\
\hline$<25$ years old & 308 & 74,6 \\
\hline $25-40$ years old & 78 & 18,9 \\
\hline $41-56$ years old & 22 & 5,3 \\
\hline$>56$ years old & 5 & 1,2 \\
\hline Total & 413 & 100 \\
\hline \multicolumn{3}{|l|}{ Gender } \\
\hline Male & 271 & 65,6 \\
\hline Female & 142 & 34,4 \\
\hline Total & 413 & 100 \\
\hline \multicolumn{3}{|l|}{ Education Background } \\
\hline SMA & 93 & 22,5 \\
\hline S-1 & 289 & 70 \\
\hline S-2 & 31 & 7,5 \\
\hline Total & 413 & 100 \\
\hline \multicolumn{3}{|l|}{ Investment Experience } \\
\hline $1-5$ years & 384 & 93 \\
\hline $6-10$ years & 22 & 5,3 \\
\hline $11-15$ years & 7 & 1,7 \\
\hline Total & 413 & 100 \\
\hline \multicolumn{3}{|l|}{ Investment Portfolio } \\
\hline$<$ Rp5.000.000 & 236 & 57,1 \\
\hline Rp5.000.000 - Rp15.000.000 & 72 & 17,4 \\
\hline Rp15.000.001 - Rp25.000.000 & 36 & 8,7 \\
\hline$>\operatorname{Rp} 25.000 .000$ & 69 & 16,7 \\
\hline Total & 413 & 100 \\
\hline
\end{tabular}

Table 3. Convergent Validity and Reliability Test

\begin{tabular}{lcccc}
\hline \multicolumn{1}{c}{ Variables } & No of Items & AVE & $\begin{array}{c}\text { Cronbach's } \\
\text { Alpha }\end{array}$ & $\begin{array}{c}\text { Composite } \\
\text { Reliability }\end{array}$ \\
\hline Investor Sentiment & 3 & 0,755 & 0,623 & 0,799 \\
Overconfidence & 5 & 0,728 & 0,778 & 0,849 \\
Salience & 4 & 0,725 & 0,698 & 0,815 \\
Overreaction & 4 & 0,746 & 0,722 & 0,830 \\
Herding & 4 & 0,755 & 0,748 & 0,841 \\
Investment decision making & 4 & 0,735 & 0,713 & 0,823 \\
\hline
\end{tabular}


Table 4 shows the hypothesis testing. Hypothesis 1 is accepted. These findings support previous research by Metawa et al. (2019) sentiment has a positive effect on investment decision making. This indicates that investors in Indonesia in making decisions are influenced by their belief in the company's future cash flows even though they are not supported by (fundamental) accounting information. The sentiment is closely related to a high level of optimism or pessimism from an investor regarding individual stocks and market conditions. This study proves the role of changes in investor sentiment in Indonesia as a market risk that is included in systemic risk is a critical aspect in portfolio management and investment decision making.

Hypothesis 2 is also accepted. This finding is consistent with the results of research by Lim (2012), Bakar and Yi (2016), and Metawa et al. (2019), who found that overconfidence has a significant positive impact on investment decision making. This means that investors who feel they have high competence will be more active in trading stocks in the capital market because they are confident and tend to underestimate risks. In a sense, they consider themselves smart participants in the capital market and believe that they can get a higher return. Overconfidence is a tendency of unconscious decision-makers to give excessive weight to the knowledge and accuracy of the information they have. Overconfidence is irrational behavior because decision-making is not based on rationality, which refers to determining the largest expected utility. Pitz (1974) argues that overconfidence tends to position one's knowledge too high and reduces the level of difficulty faced, so people with high overconfidence do not recognize uncertainty; they believe themselves to be able to overcome or solve any problem at hand.

Hypothesis 3 is accepted. This study's results are in line with the research of Chaudary (2018) and Yalcin et al. (2016), who show that salience has a positive effect on investment decisions. This means that investors in Indonesia prefer to invest in better-known companies because doing so tends to increase the level of confidence and optimism. In addition, it can also be interpreted that investors in Indonesia are proven not to be completely rational by relying on shortcuts such as choosing to invest in well-known stocks. Thus, this study confirms the heuristic theory in which irrational investors use heuristics in decision making. That's because irrational people don't collect all the information. They follow shortcuts that make their decision-making process easier.

Hypothesis 4 is accepted. This study's results are in line with research by Metawa et al. (2019) who show that overreaction has a positive effect on investment decision making. This implies that investors in Indonesia systematically overreact to unexpected information that 
enters the capital market so that an extreme response occurs at a certain time. Thus, it can be seen that investors are not fully rational in making investment decisions because investors are proven to tend to overload positive or negative news that leads to excessive increases or decreases in stock prices.

Hypothesis 5 is also accepted. Herding behavior is proven to have a positive effect on investment decision making. This result is in line with Waweru et al. (2008), who found that herding can encourage stock investment decision making and create momentum. Waweru et al. (2008) also concluded that others' decisions significantly influence an investor's buying and selling decisions. Chang et al. (2000) argued that herding behavior is more prevalent in emerging markets. Herding behavior is the most common mistake in which investors tend to follow the majority in making investment decisions, which will impact changes in investment decisions taken (Gozalie and Anastasia, 2015). Herding behavior can be seen, mostly when the stock market is falling because investors will flock to sell shares simultaneously for fear of losing their capital and vice versa when the market is rising.

Table 4. Hypothesis Testing

\begin{tabular}{llccc}
\hline \multicolumn{1}{c}{ Hypothesis } & $\begin{array}{c}\text { Path } \\
\text { Coefficient }\end{array}$ & p-values & Result \\
\hline $\mathrm{H}_{1}:$ & $\begin{array}{l}\text { Investor sentiment has a positive } \\
\text { impact on investment decision } \\
\text { making }\end{array}$ & 0,11 & $<0,01$ & Accepted \\
$\mathrm{H}_{2}:$ & $\begin{array}{l}\text { Overconfidence has a positive } \\
\text { impact on investment decision } \\
\text { making }\end{array}$ & 0,13 & $<0,01$ & Accepted \\
$\mathrm{H}_{3}: \quad \begin{array}{l}\text { Salience has a positive impact on } \\
\text { investment decision making }\end{array}$ & 0,12 & $<0,01$ & Accepted \\
$\mathrm{H}_{4}: \quad \begin{array}{l}\text { Overreaction has a positive impact } \\
\text { on investment decision making }\end{array}$ & 0,15 & $<0,01$ & Accepted \\
$\mathrm{H}_{5}:$ & $\begin{array}{l}\text { Herding has a positive impact on } \\
\text { investment decision making }\end{array}$ & 0,44 & $<0.01$ & Accepted \\
\hline
\end{tabular}

\section{CONCLUSION}

Investor need to make investment decision making when they choose to invest in some securities. Investors are required to make optimal investment decisions. Therefore, investors need to analyze information in the decision making process (Puspitaningtyas, 2013). There are several theories that have been developed regarding investment decision making, namely classical financial theory and modern financial theory related to financial behavior. Classical financial theory related to efficient market hypothesis. Efficient market hypothesis explain that investor always make a rational decision and also price in the market is reflected the 
information that investor need. Classical financial theory is also related to fundamental analysis. However in modern financial theory showed that sometimes investor cannot make a rational decision because there are behavioral biases. Behavioral biases emerge due to the limitation ability of investor to do technical and fundamental analysis (Krishnamurti, 2009)

The phenomenon of a market crash and yields on stock investment in the Indonesian Capital Market that are still less attractive in line with the sell-off by investors need to be highlighted regarding the importance of understanding the factors that influence investment decision making by individuals. Empirical studies prove that investors are not fully rational, but investment decisions are also driven by behavior. In line with Metawa et al. (2019) showed that the behavioral factors that influence investment decisions are investor sentiment, overconfidence, overreaction, and herding behavior. In addition, Yalcin et al. (2016) and Chaudary (2018) found that salience influences investment decision making.

There are several implication of this study, behavioral aspect can influence investment decision making. A central bank can integrate behavioral finance in educating investment for the public, so it is hoped that individual investors can make better investment decisions and avoid biased behavior. Next, considering behavioral factors into the policy-making related to investor protection rights as well as for the stability and smoothness of the capital market. Further, increase awareness to customers about the impact of biased behavior in investing in stocks and provide more reliable consulting and guidance to investors on making an acceptable investment strategy.

The investor can update the latest news on factors that can affect sentiment, including macro policies, similar industrial policies, and policies of the central bank. Next, making an investment plan by making criteria for what stocks to be selected as a portfolio and what conditions determine the decision to buy or sell stocks. Further, periodically rebalancing the portfolio according to the investor's investment objectives and stopping excessive selling/buying transactions. Investors also can reduce subjectivity by discussing with other, more reliable investors. Further, an investor can diversify its portfolio to avoid anomalies triggered by salience behavior and minimize risks.

\section{REFERENCES}

Agarwal, S., Chiu, I. M., Liu, C., and Rhee, S. G. (2011). The Brokerage Firm Effect in Herding: Evidence from Indonesia. Journal of Financial Research, 461-479.

Bakar, S., and Yi, A. N. (2016). The Impact of Psychological Factors on Investors' Decision Making in Malaysian Stock Market: a Case of Klang Valley and Pahang. Procedia Economics and Finance, 319-328. 
Baker, H. K., Fillbeck, G., and Ricciardi, V. (2017). How Behavioural Biases Affect Finance Professionals. The European Financial Review, 25-29.

Barber, B., and Odean, T. (2001). Boys Will Be Boys: Gender, Overconfidence, and Common Stock Investment. Quarterly Journal of Economics, 261-292.

Biais, B., Hilton, D., Mazurier, K., and Pouget, S. (2002). Psychological Traits and Trading Strategies. Financial Economics, 1-29.

Brown, G. W. (1999). Volatility, Sentiment, and Noise Traders. Financial Analysts Journal, $82-90$.

Brown, G. W., and Cliff, M. T. (2004). Investor Sentiment and The Near-Term Stock Market. Journal of Empirical Finance, 1-27.

Chaudary, S. (2018). Does Salience Matter in Investment Decision? Differences Between Individual and Professional Investors. Kybernetes.

Chang, E. C., Cheng, J. W., and Khorana, A. (2000). An Eximination of Herd Behavior in Equity Markets: An International Perspective. Journal of Banking and Finance, 16511679.

Changseng, H., and Yongfeng, W. (2012). Investor Sentiment and Assets Valuation. Systems Engineering Procedia, 166-171.

Christanti, N., dan Mahastanti, L. A. (2011). Faktor-faktor yang Dipertimbangkan Investor dalam Melakukan Investasi. Jurnal Manajemen Teori dan Terapan, 37-51.

Daniel, K., Hirshleifer, D., and Subrahmanyam, A. (1998). Investor Psychology and Security Market Under-and Overreactions. The Journal of Finance, 1839-1885.

De Bondt, W. F., and Thaler, R. (1985). Does The Stock Market Overreact? The Journal of Finance, 793-805.

Del Giudice, A., and Paltrinieri, A. (2017). The Impact of The Arab Spring and The Ebola Outbreak on African Equity Mutual Fund Investor Decisions. Research in International Business and Finance, 600-612.

Eagly, A. H., and Carli, L. L. (1981). Sex of Researchers and Sex-Typed Communications as Determinants of Sex Differences in Influenceability: a Meta-Analysis of Social Influence Studies. Psychological Bulletin, 1.

Glaser, M., and Weber, M. (2007). Overconfidence and Trading Volume. The Geneva Risk and Insurance Review, 1-36.

Gozalie, S., dan Anastasia, N. (2015). Pengaruh Perilaku Heuristics dan Herding terhadap Pengambilan Keputusan Investasi Properti Hunian. Finesta, 28-32.

Huberman, G. (2001). Familiarity Breeds Investment. Review of Financial Studies, 659-680.

Ivada, W. (2010). Pengaruh Kompetensi Investor dan Overconfidence terhadap Frekuensi Perdagangan. Surakarta: Universitas Sebelas Maret.

Krishnamurti, C. (2009). Investment Management: A Modern Guide to Security Analysis and Stock Selection. Heidelberg: Springer.

Kufepaksi, M. (2007). The Effect of Overconfident Behavior on the Process of Forming and Correcting. Dissertation.

Lestari, S., dan Yulianto, A. (2018). Analisis Stock Mispricing terhadap Return Reversal Saham pada Bursa Efek Indonesia. Management Analysis Journal, 63-75.

Luong, L. P., and Ha, D. T. (2011). Behavioral Factors Influencing Individual Investors' Decision-Making and Performance a Survey at The Ho Chi Minh Stock Exchange. Asian Journal of Finance and Accounting, 15-28.

Metawa, N., Hassan, M. K., Metawa, S., and Safa, M. F. (2019). Impact of Behavioral Factors on Investors' Financial Decisions: Case of The Egyptian Stock Market. Interantional Journal of Ismlamic and Middle Eastern Finance and Management, 30-55.

Ottemoesoe, R. S., dan Malelak, M. I. (2014). Fenomena Reaksi Berlebihan atau Overreaction pada Transaksi Saham di Asia Tenggara. Forum Manajemen Indonesia, 1-13. 
Piccoli, P., Chaundhury, M., and Souza, A. (2017). How Do Stocks React to Extreme Market Events? Evidence from Brazil. Research in International Business and Finance, 275284.

Pitz, G. F. (1974). Subjective Probability Distributions for Imperfectly Known Quantities.

Prastiyo, F. A. (2012). Analisis Overreaction Saham Perusahaan yang Terdaftar di Bursa Efek Indonesia Periode 1995-2010. Surabaya: Petra Christian University.

Puspitaningtyas, Z. (2013). Perilaku Investor dalam Pengambilan Keputusan Investasi di Pasar Modal. Prosiding Seminar Nasional dan Call for Paper Forum Manajemen Indonesia.

Shefrin, H. (2000). Beyond Greed and Fear: Understanding Behavioral Finance and Psychology of Investing. New York: Harvard Business School Press.

Waweru, N. M., Munyoki, E., \& Uliana, E. (2008). The Effects of Behavioural Factors in Investment Decision-Making: a Survey of Institutional Investors Operating at The Nairobi Stock Exchange. International Journal of Business and Emerging Markets, 2441.

Yalcin, K. C., Tatoglu, E., \& Zaim, S. (2016). Developing an instrument for measuring the effects of heuristics on investment decisions. Kybernetes, 1052-1071. 